Fountain Journal of Natural and Applied Sciences: 2016; 5(1): 19 - 24
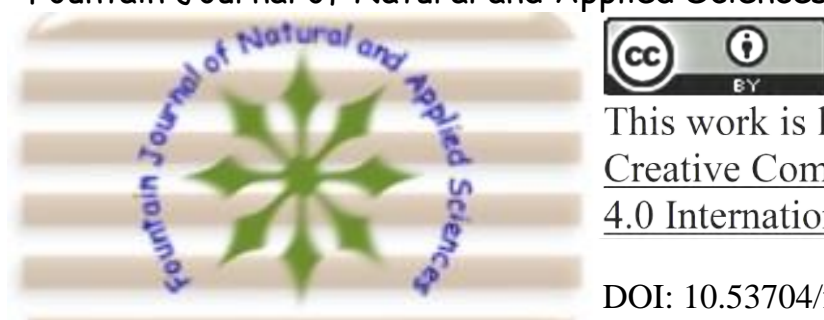

This work is licensed under Creative Commons Attribution 4.0 International License.

DOI: 10.53704/fujnas.v5i1.84

A publication of College of Natural and Applied Sciences, Fountain University, Osogbo, Nigeria. Journal homepage: www. fountainjournals.com

ISSN: 2354-337X (Online), 2350-1863 (Print)

\title{
Gas Chromatography-Mass Spectrometry and Cytotoxicity of Securidaca longepedunculata (polygalaceae) Root Bark Extract
}

\author{
Lawal R.A. ${ }^{1}$, Odesanmi O.S. ${ }^{1}$, Ozaslan M.D. ${ }^{2}$, Ebuehi O.A.T. ${ }^{1}$, Karagoz I.D. ${ }^{2}$, Kilic I.H. ${ }^{2}$, \\ Uyar $C^{2}{ }^{2}$, Badmus I. $A^{1}$. \\ ${ }^{1}$ Department of Biochemistry, College of Medicine, University of Lagos, Lagos, Nigeria. \\ ${ }^{2}$ Department of Biology, University of Gaziantep, 27310 Gaziantep, Turkey.
}

\begin{abstract}
Securidaca longepedunculata is a savannah shrub found growing in tropical Africa. It is reputed to have more than a hundred medicinal uses and is a major component of anticancer decoctions in Nigeria. Despite its reported use as an anti-cancer plant, there is a dearth of information on the anti-cancer potential and mechanism of its anticancer activity. The present study is to identify the chemical constituents present in Securidaca longepedunculata by quantitative Gas Chromatography-Mass Spectrometry (GC-MS) analysis and determine the cytotoxic effect of the plant on Ehrlich ascites carcinoma cells. Secondary metabolites in the extract were predicted using GC-MS. In vitro cytotoxic activity was determined using the trypan blue dye exclusion assay by incubating Ehrlich ascites carcinoma cells with various concentrations of $S$. longepedunculata aqueous extract. Analysis by GC-MS revealed the presence of the following compounds: bis (2-ethylhexyl) phthalate (90.99\%), 1-decanol (4.17\%) and cyclododecane (1.86\%), phenol, 2, 21-methylene bis (1.32\%), cyclopenten-4-one, 3-hydroxy-1, 2, 3, 5, 5'-pentakis (trimethylsilyloxy)- (0.89\%) and phenol, 2, 4-bis (1,1-dimethylethyl)(0.78\%). Securidaca longepedunculata aqueous extract (SL) was cytotoxic to Ehrlich ascites carcinoma cells in vitro. The IC 50 of SL on EAC cells was $67 \mu \mathrm{g} / \mathrm{ml}$. The aqueous root-bark extract of $S$. longepedunculata contains bioactive agents and was cytotoxic to Ehrlich ascites carcinoma cells in vitro.
\end{abstract}

Keywords: phthalate, Ehrlich, carcinoma, medicinal, plants

\section{Introduction}

The increase in the use of medicinal plants in the treatment and diagnosis of ailments in Africa and other parts of the world has been documented (Shoeb, 2006; Saluja et al., 2011). Securidaca longepedunculata (Polygalaceae) is a medicinal plant found growing in some countries including Nigeria. It is used in the treatment of variety of ailments in Nigeria hence the name Uwar Magunguna (Mother of all drugs) by the Hausas in Northern Nigeria (Dapar et al., 2007).
It has been reported as an essential part of anticancer decoctions in South-West Nigeria (Soladoye et al., 2010). The constituents of $S$. longepedunculata were investigated and four novel highly oxygenated xanthones, named muchimangins $A-D$ were reported (Dibwe et al., 2012b). The plant also displayed potent preferential cytotoxicity when tested on a human pancreatic cancer PANC-1 cell line in a nutrient-

Corresponding author: +2348056036852

Email address: alawal@unilag.edu.ng 
deprived medium (Dibwe et al., 2012a). Several cancer cell lines are employed in testing for cytotoxic compounds amongst which is Ehrlich ascites carcinoma (EAC) cells - spontaneous murine mammary adenocarcinoma adapted to ascites form and carried in outbred mice (Ozaslan et al., 2011). There is currently a dearth of information on the in vitro potential of Securidaca longepedunculata on mammary cancer cell lines. Hence, the objective of this research is to investigate the cytotoxic activity of aqueous root-bark extract of Securidaca longepedunculata using EAC cells from mice peritoneal cavity and determine the bioactive components in the extract.

\section{Methodology \\ Plant collection}

Securidaca longepedunculata root barks were collected from Osogbo, South-West, Nigeria in January, 2010. Plant material was identified and authenticated by Mr Odewo in the Department of Botany, University of Lagos in January, 2010. A voucher specimen was deposited in the University Herbarium, University of Lagos, Lagos, Nigeria with voucher number: LUH 3593.

\section{Preparation of aqueous extract of Securidaca longepedunculata}

The plant materials were shade dried for 3 days and pulverized into powder. Aqueous extract of the coarsely powdered material was prepared by macerating $1 \mathrm{~kg}$ of root bark in $1 \mathrm{~L}$ of distilled water for 72 hours. The macerate was filtered and the filtrate was concentrated using the Rotary Evaporator (Rotavapor ${ }^{\circledR}$ R-300, BUCHI, Switzerland) and further concentrated to constant weight in vacuo using a lyophilizer (Lyotrap, LTE, England).

\section{Gas chromatography-mass spectrometry (GC-MS)}

The modified method of Botes et al. (2008) was used for the characterization of the secondary metabolites of the aqueous root-bark extract of Securidaca longepedunculata. The analysis was carried out with Agilent 6890 GC coupled to a 5973 MS detector (California, U.S.A). For the acquisition of an electron ionization mass spectrum, an ion source temperature of $200^{\circ} \mathrm{C}$ and electron energy of $70 \mathrm{eV}$ was used. Helium (1
$\mathrm{mL} / \mathrm{min}$ ) was used as the carrier gas. The oven temperature programme for analyzing the aqueous extract utilized an initial oven temperature of $40^{\circ} \mathrm{C}$, maintained for $2 \mathrm{~min}$, followed by a steady climb to $350^{\circ} \mathrm{C}$ at a rate of $5^{\circ} \mathrm{C} / \mathrm{min}$.

\section{Short term Cytotoxicity study}

In vitro cytotoxic activity was carried out using the Trypan Blue dye exclusion method. Briefly, aqueous extract of Securidaca longepedunculata in Phosphate buffered saline $(1000,100,10,1$ and $0.1 \mu \mathrm{g} / \mathrm{ml})$ were incubated with EAC cells at $37^{\circ} \mathrm{C}$ for $25 \mathrm{~h}$ after which cells were stained with trypan blue dye (Sigma-Aldrich, St. Louis, USA). Ascitic tumour cell counts were done in a Cedex Cell Counting machine (Roche, California) in which viable cells were unstained and damaged cells were stained blue. Results were expressed as percentage cell viability (Saluja et al., 2011). \% Mortality $=100$ - \% cell viability.

\section{Statistical Analyses}

This was carried out using SPSS $\vee 17.0$ statistical package. Results are expressed as Mean \pm standard error of the mean. Student's t-test was used to test for the differences in mean values between the groups and control. The I $C_{50}$ was calculated using the Finney Probit Analysis method (Finney, 1947).

\section{Results}

The results of GC-MS for Securidaca longepedunculata are shown in Table 1. More than 6 compounds were detected in six peaks for the aqueous extracts of $S$. longepedunculata. The results revealed that bis (2-ethylhexyl) phthalate $(90.98 \%)$ was found as the major compound while 1-Decanol (4.17\%) and Cyclododecane (1.86\%) was the other compound with relatively high composition. Other compounds detected were phenol, 2, $2^{1}$-methylene bis $(1.32 \%)$, cyclopenten4-one, 3-hydroxy-1，2，3，5，51-pentakis (trimethylsilyloxy) - (0.89\%) phenol, 2, 4-bis (1, 1dimethylethyl) (0.78\%). Securidaca longepedunculata at concentrations of $0.1,1,10$, $100,1000 \mu \mathrm{g} / \mathrm{ml}$ caused mortalities of $7.3,10.6$, 27.9, 45.1 and $82.5 \%$ respectively in Ehrlich ascites carcinoma cells. The death rate of Ehrlich 
Table 1: GC-MS Peaks and components of aqueous extract of S. longepedunculata

\begin{tabular}{|c|c|c|c|c|c|c|}
\hline \multirow[b]{2}{*}{ Peak } & \multirow[b]{2}{*}{ RT (mins) } & \multirow[b]{2}{*}{ Library/ID } & \multicolumn{3}{|c|}{ Mol. Formula } & \multirow{2}{*}{$\begin{array}{l}\text { Compound } \\
\text { Nature }\end{array}$} \\
\hline & & & & MW & Area $(\%)$ & \\
\hline 1 & 6.3281 & $\begin{array}{l}\text { Cyclopenten-4-one,3- } \\
\text { hydroxy-1,2,3,5,5-pentakis } \\
\text { (trimethylsilyloxy)- }\end{array}$ & $\mathrm{C}_{20} \mathrm{H}_{46} \mathrm{O}_{7} \mathrm{Si}_{5}$ & 538 & 0.89 & $\begin{array}{l}\text { Ketone } \\
\text { compound }\end{array}$ \\
\hline 2 & 11.8961 & 1-Decanol & $\mathrm{C}_{10 \mathrm{H}_{22} \mathrm{O}}$ & 158 & 4.17 & Alcohol \\
\hline 3 & 12.1688 & $\begin{array}{l}\text { Phenol, 2, 4-bis } \\
\text { (1,1-dimethylethyl)- }\end{array}$ & $\mathrm{C}_{14} \mathrm{H}_{22} \mathrm{O}$ & 206 & 0.78 & $\begin{array}{l}\text { Phenolic } \\
\text { compound }\end{array}$ \\
\hline 4 & 13.4418 & Cyclododecane & $\mathrm{C}_{12} \mathrm{H}_{24}$ & 168 & 1.86 & $\begin{array}{l}\text { Hydrocarbon } \\
\text { Phenolic }\end{array}$ \\
\hline 5 & 26.1234 & Phenol, 2,2'-methylenebis & $\mathrm{C}_{13} \mathrm{H}_{12} \mathrm{O}_{2}$ & 200 & 1.32 & compound \\
\hline 6 & 27.1824 & bis (2-ethylhexyl) ester & $\mathrm{C}_{24} \mathrm{H}_{38} \mathrm{O}_{4}$ & 390 & 90.98 & Ester Compound \\
\hline
\end{tabular}

R.T. - Retention time, M.W. - Molecular weight

ascites tumour cells in-vitro increases with increasing concentration of $S$. longepedunculata root bark extract (Table 2). The $I C_{50}$ (i.e. the lethal concentration that kills $50 \%$ of cells) was calculated to be $67 \mu \mathrm{g} / \mathrm{ml}$.

Table 2: In vitro cytotoxic effect of aqueous extracts of Securidaca longepedunculata on Ehrlich Ascites Carcinoma cells.

\begin{tabular}{ll}
\hline Concentration $(\mu \mathrm{g} / \mathrm{ml})$ & Mortality $(\%)$ \\
\hline 1000 & $82.5 \pm 5.02^{\mathrm{d}}$ \\
100 & $45.1 \pm 1.56^{\mathrm{c}}$ \\
10 & $27.9 \pm 0.29^{\mathrm{b}}$ \\
1 & $10.6 \pm 0.40^{\mathrm{a}}$ \\
0.1 & $7.3 \pm 0.35^{\mathrm{a}}$ \\
\hline
\end{tabular}

*Results are expressed as Mean of 3 determinations \pm Standard error of the mean

\section{Discussion}

Gas, Chromatography-Mass Spectrometry is an analytical technique which combines the features of gas-chromatography and mass spectrometry to identify different substances with a potential to quantify within a test sample
(Al-Doush et al., 2012). In this study, Gas Chromatography-Mass Spectrometry analysis of 5 . longepedunculata root bark extract led to the identification of 6 compounds; bis (2-ethylhexyl) phthalate, 1-decanol, cyclododecane, phenol, 2, 21methylene bis, cyclopenten-4-one, 3-hydroxy-1, 2, 3, 5, $5^{1}$-pentakis (trimethylsilyloxy) and phenol, 2 , 4-bis (1, 1-dimethylethyl). According to Lahousse et al. (2006), phthalates are chemicals majorly used as softening agents in plastic-containing products. The phthalates are not covalently bound to the matrix. They therefore leach out of the plastic materials after some time and result in environmental contamination. Phthalate exposure inhibited follicle stimulating hormone (FSH)stimulated CAMP production and suppressed basal and FSH-stimulated Sertoli cell proliferation (Heindel and Chapin, 1989; Li et al., 1998). In rodents, high-dose phthalate exposure targets the fetal and pubertal testis, leading to alterations in endocrine and spermatogenic functions (Boekelheide et al., 2004). Habib and Karim (2009) confirmed the cytotoxic activity of bis (2-ethyl hexyl) phthalate. Joo et al. (2010) reported that white rose flower extract, 
containing a high amount of cyclododecane, strongly scavenged free radicals in a dosedependent manner and also inhibited the growth of E. coli. In a study by Wang et al. (2012), Eryngiolide A (I), - C20 diterpenoid derived from a cyclododecane core isolated from edible mushroom Pleurotus eryngii was found to exhibit moderate cytotoxicity against two human cancer lines, HeLa and HepG2, in vitro using the MTT (3[4,5-dimethylthiazole-2-yl]-2,5-diphenyl

tetrazolium bromide) method. Phenol, 2, 4-bis (1,1dimethylethyl)- was recognized as the compound responsible for the high antibacterial activity of Mango kernel against gram positive bacteria (Abdullah et al., 2011). A study by Prakash and Suneetha (2014) showed that Pinus granatum rind extract containing phenol, 2, 4-bis (1,1dimethylethyl)- exhibited a better antioxidant activity than $L$ - ascorbic acid. The antimicrobial activity of phenol, 2, 4-bis (1,1-dimethylethyl)appeared to correlate with the antioxidative activity associated with this compound, because it was able to inhibit the ROS production in both Aspergillus and Phytophthora cinnamomi hence regulating hydrogen peroxide production (Romero-Correa et al., 2014). Among the identified phytochemicals, 2, 21-methylenebis(6(1,1-dimethylethyl)-4-ethyl-phenol (an analogue of phenol 2, $2^{1}$ methylenebis) belongs to a class of compounds with powerful antimicrobial and antiseptic properties which further confirms the cytotoxic potential of the extract (Celis et al., 2011). Marko et al. (2002) reported that 3hydroxy-4-[(E)-(2-furyl) methylidene] methyl-3cyclopentene-1,2-dione (an intensively coloured Maillard reaction product) also inhibited tumor cell growth and microtubule assembly.

In the US National Cancer Institute plant screening programme, a crude extract is generally considered to have in vitro cytotoxic activity if the IC 50 value (Inhibitory Concentration that causes a $50 \%$ cell kill) in carcinoma cells, following incubation between 48 and 72 hours, is less than $20 \mu \mathrm{g} / \mathrm{ml}$, while it is less than $4 \mu \mathrm{g} / \mathrm{ml}$ for pure compounds (Boik, 2001). The trypan blue exclusion assay is a direct, simple and inexpensive method of determining the relative amount of damaged cells. The trypan blue exclusion assay used in the in vitro cytotoxic study relies on the exclusion of intact and viable cells by the negatively charged trypan blue dye which is taken up by damaged and dead cells (Choudhury et al., 2010). A relatively high number of cells remained unstained in the tube that had no extract while the number of stained cells was high in the tubes to which extracts were added. This indicates a direct cytotoxic effect of the extract on Ehrlich ascites carcinoma cells. This effect was observed to increase with concentration of Securidaca longependuculata root bark extract suggesting that the quantity of the cytotoxic agent increased with concentration of Securidaca longependuculata root bark extract. The low IC 50 of $67 \mu \mathrm{g} / \mathrm{ml}$ recorded in this study suggests that the aqueous root bark extract of $S$. longepedunculata, which has been shown to possess agents, such as Phenol, 2,2' -methylenebis and phenol, 2, 4-bis (1,1-dimethylethyl), implicated in cell-lysing possesses significant in vitro cytotoxic activity.

\section{Conclusion}

Aqueous root-bark extract of Securidaca longepedunculata contained cytotoxic bioactive agents which are thought to be responsible for its cytotoxic activity against Ehrlich ascites carcinoma cells in vitro.

\section{Acknowledgements}

The authors will like to thank the authorities of the University of Lagos, Lagos, Nigeria for permission to conduct the research in the Molecular Biology Laboratory, Department of Biology, University of Gaziantep, Gaziantep, Turkey and Dr. F.K Lawal for co-sponsoring the trip.

\section{References}

Abdullah, A. H., Elwathig, M., Mirghani, S. and Jamal, P. (2011) Antibacterial activity of Malaysian mango kernel. African Journal of Biotechnology, 10(81):18739-18748.

Al-Doush, I.I., Mahier, T.J., Al Tufail, M. and Bogusz, M.J. (2012) Occurrence of Osthole in commonly available citrus fruits analyzed with GC-MS and LC-QTOF-MS. International Journal of Applied Research in Natural Products, 5(4): 37-43.

Boekelheide, K., Johnson, K. J. and Richburg, J. H. (2004). Sertoli cell toxicants. In Sertoli 
Cell Biology (M. K. Skinner and M. D. Griswold, Eds.), pp. 345-382. Academic Press, San Diego, CA.

Boik, J. (2001). Natural Compounds in Cancer Therapy. Oregon Medical Press, Minessota, USA, p 25.

Botes, L., van der Westhuizen, F. H. and Loots, D. T. (2008). Phytochemical contents and antioxidant capacities of two Aloe greatheadii var. davyana extracts. Molecules, 13: 2169-2180.

Celis, C., García, A., Sequeda, G., Mendez, G. and Torrenegra, R. (2011). Antimicrobial activity of extracts obtained from Anacardium excelsum against some pathogenic microorganisms. Emirates Journal of Food and Agriculture, 23 (3): 249-257.

Choudhury, S.M., Gupta, M. and Majumder, U. K. (2010) Antineoplastic activities of MT81 and its structural analogue in Ehrlich ascites carcinoma-bearing swiss albino mice. Oxidative Medicine and Cellular Longevity 3(1): 61-70.

Dapar, L. P. M., Aguiyi, C. J., Wannang, N. N., Gyang, S. S. and Tanko, M. N. (2007). The histopathologic effects of Securidaca longepedunculata on heart, liver, kidney and lungs of rats. African Journal of Biotechnology, 6 (5): 591-595.

Dibwe, D. F., Awale, S., Kadota, S. and Tezuka, Y. (2012a). Damnacanthal from the Congolese medicinal plant Garcinia huillensis has a potent preferential cytotoxicity against human pancreatic cancer PANC-1 cells. Phytotherapy Research, 26: 1920- 1926.

Dibwe, D. F., Awale, S., Kadota, S. and Tezuka, Y. (2012b). Muchimangins A-D: novel diphenylmethyl-substituted xanthones from Securidaca longepedunculata. Tetrahedron Letters, 53: 6186-6190.

Finney, D. J. (1947). Probit Analysis: A Statistical Treatment of Sigmoid Response Curve. Cambridge Press, Cambridge.

Habib, M. R. and Karim, M. R. (2009). Antimicrobial and cytotoxic activity of di-(2-ethylhexyl) phthalate and anhydrosophoradiol-3acetate isolated from Calotropis gigantea (Linn.) flower. Mycobiology, 37(1): 31-36.
Heindel, J. J. and Chapin, R. E. (1989). Inhibition of FSH-stimulated CAMP accumulation by mono(2-ethylhexyl) phthalate in primary rat Sertoli cell cultures. Toxicology and Applied Pharmacology, 97: 377-385.

Joo, S. S., Kim, Y.B. and Lee, D.I. (2010). Antimicrobial and antioxidant properties of secondary metabolites from white Rose flower. Plant Pathology Journal, 26(1): 5762.

Lahousse, S. A., Beall, S. A. and Johnson, K. J. (2006). Mono-(2-ethylhexyl) Phthalate rapidly increases Celsr2 protein phosphorylation in HeLa Cells via protein kinase $C$ and casein kinase 1 . Toxicological Sciences, 91(1): 255-264.

Li, L. H., Jester, W. F. Jr. and Orth, J. M. (1998). Effects of relatively low levels of mono(2-ethylhexyl) phthalate on cocultured Sertoli cells and gonocytes from neonatal rats. Toxicology and Applied Pharmacology, 153: 258-265.

Marko, D., Kemény, M., Bernady, E., Habermeyer, M., Weyand, U., Meiers, S., Frank, O. and Hofmann, T. (2002). Studies on the inhibition of tumor cell growth and microtubule assembly by 3-hydroxy-4[(E)-(2-furyl)methylidene]methyl-3cyclopentene-1,2-dione, an intensively coloured Maillard reaction product. Food and Chemical Toxicology, 40(1): 9-18.

Ozaslan, M., Karagoz, I. D., Kilic, I. H. and Guldur, M. E. (2011). Ehrlich ascites carcinoma. African Journal of Biotechnology, 10(13): 2375-2378.

Prakash, A. and Suneetha, V. (2014). Punica granatum (Pomegranate) Rind extract as a potent substitute for $L$ ascorbic acid with respect to the antioxidant activity. Research Journal of Pharmaceutical, Biological and Chemical Sciences 5(2) 597 603.

Romero-Correa, M. T., Villa-Gómez, R., CastroMercado, E. and García-Pineda, E. (2014) The avocado defense compound phenol2,4-bis (1,1-dimethylethyl) is induced by arachidonic acid and acts via the inhibition of hydrogen peroxide production by 
pathogens. Physiological and Molecular Plant Pathology, 87:32-41.

Soladoye, M. O., Amusa, N. A., Raji-Esan, S.O., Chukwuma, E. C. and Taiwo, A. A. (2010). Ethnobotanical Survey of Anti-Cancer Plants in Ogun State, Nigeria. Annals of Biological Research., 1 (4): 261-273.

Saluja, M. S., Sangameswaran, B., Hura, I. S., Sharma, A., Gupta, S. K. and Chaturvedi, M. (2011). In-vitro cytotoxic activity of leaves of Madhuca longifolia against Ehrlich ascites carcinoma (EAC) cell lines.
International Journal of Drug Discovery and Herbal Research 1(2): 55-57.

Shoeb, M. (2006). Anticancer agents from medicinal plants. Bangladesh Journal of Pharmacology 1: 35-41.

Wang, S., Li, Y.X., Li, B., Han, J.J., Yang, X.L., Li, H.R., Wang, Y.Q., Li, S.J. and Liu, H.W. (2012). Eryngiolide A, a cytotoxic macrocyclic diterpenoid with an unusual cyclododecane core skeleton produced by the edible mushroom Pleurotus eryngii. Organic Letters, 14(14): 3672-5. 